Article

\title{
Embryotoxicity of Selective Serotonin Reuptake Inhibitors-Comparative Sensitivity of Zebrafish (Danio rerio) and African Clawed Frog (Xenopus laevis) Embryos
}

\author{
Jana Blahova ${ }^{1, *}$, Veronika Doubkova ${ }^{1}$, Lucie Plhalova ${ }^{1}$, Pavla Lakdawala ${ }^{1}$, Denisa Medkova ${ }^{1}$, \\ Vladimir Vecerek ${ }^{1}$, Zdenka Svobodova ${ }^{1}$ and Caterina Faggio ${ }^{2, * \text { (D) }}$ \\ 1 Department of Animal Protection and Welfare \& Veterinary Public Health, \\ University of Veterinary Sciences Brno, 61242 Brno, Czech Republic; doubkovav@vfu.cz (V.D.); \\ plhaloval@vfu.cz (L.P.); sehonovap@vfu.cz (P.L.); h19004@vfu.cz (D.M.); vecerekv@vfu.cz (V.V.); \\ svobodovaz@vfu.cz (Z.S.) \\ 2 Department of Chemical, Biological, Pharmaceutical and Environmental Sciences, University of Messina, \\ 98166 Messina, Italy \\ * Correspondence: blahovaj@vfu.cz (J.B.); cfaggio@unime.it (C.F.)
}

\section{check for} updates

Citation: Blahova, J.; Doubkova, V.; Plhalova, L.; Lakdawala, P.; Medkova, D.; Vecerek, V.; Svobodova, Z.; Faggio, C. Embryotoxicity of Selective Serotonin Reuptake

Inhibitors-Comparative Sensitivity of Zebrafish (Danio rerio) and African Clawed Frog (Xenopus laevis)

Embryos. Appl. Sci. 2021, 11, 10015.

https://doi.org/10.3390/app112110015

Academic Editor: Francesco Cappello

Received: 5 October 2021

Accepted: 23 October 2021

Published: 26 October 2021

Publisher's Note: MDPI stays neutral with regard to jurisdictional claims in published maps and institutional affiliations.

Copyright: (c) 2021 by the authors. Licensee MDPI, Basel, Switzerland. This article is an open access article distributed under the terms and conditions of the Creative Commons Attribution (CC BY) license (https:/ / creativecommons.org/licenses/by/ $4.0 /)$.

\begin{abstract}
Over the past twenty years, the prescription of antidepressant drugs has increased all over the world. After their application, antidepressants, like other pharmaceuticals, are excreted and enter the aquatic environment. They are dispersed among surface waters mainly through waste water sources, typically at very low concentrations - from a tenth up to hundreds of ng/L. Frequently detected antidepressants include fluoxetine and citalopram - both selective serotonin reuptake inhibitors. The aim of our study was to assess the embryotoxicity of fluoxetine hydrochloride and citalopram hydrochloride on the early life stages of zebrafish (Danio rerio) and the African clawed frog (Xenopus laevis). The embryos were exposed to various concentrations of the individual antidepressants and of their mixtures for $96 \mathrm{~h}$. The tested levels included both environmentally relevant and higher concentrations for the evaluation of dose-dependent effects. Our study demonstrated that even environmentally relevant concentrations of these psychiatric drugs influenced zebrafish embryos, which was proven by a significant increase $(p<0.01)$ in the embryos' heart rates after fluoxetine hydrochloride exposure and in their hatching rate after exposure to a combination of both antidepressants, and thus revealed a potential risk to aquatic life. Despite these results, we can conclude that the African clawed frog is more sensitive, since exposure to the highest concentrations of fluoxetine hydrochloride $(10,000 \mu \mathrm{g} / \mathrm{L})$ and citalopram hydrochloride $(100,000 \mu \mathrm{g} / \mathrm{L})$ resulted in total mortality of the frog embryos.
\end{abstract}

Keywords: antidepressant; early-life stages; mortality; hatching; lethal and sublethal endpoints

\section{Introduction}

The welfare of aquatic organisms can be significantly disturbed by exposure to various biologically active chemical compounds, even at sublethal concentrations, which mainly enter the aquatic environment due to intense anthropogenic activity [1-10]. In recent years, the growing concentration of pharmaceuticals entering the aquatic ecosystem, which is mainly due to insufficiently treated wastewater from hospitals, households and other facilities, has become a topical issue [11-13]. Among a large number of pharmaceuticals, antidepressants have received significant attention in many ecotoxicological studies [14-16]. According to the OECD statistics, the prescription and consumption of these medications increase every year, even though their use often has various adverse effects (e.g., apathy, a loss of motivation, nausea, tremor, sexual dysfunction). In the Czech Republic, their increase was recorded more than six times in the period from 2000 to 2017 . It is also a significant assumption that this trend will continue in the upcoming years $[17,18]$. 
Antidepressants represent an important group of drugs that is widely used in the treatment of various mental disorders (e.g., depression, bipolar disorder, schizophrenia, other psychoses, chronic pain, autism, insomnia, anorexia). The main function of antidepressants is to create a neurohumoral balance by influencing the activity of neurotransmitters $[12,14,19]$. According to the mechanism of action, they can be divided into several groups. Tricyclic antidepressants, so-called first-generation antidepressants, are among the oldest types of drugs used in the treatment of depression that act as a blocker of the reuptake of one or more neurotransmitters. Unfortunately, they have more adverse effects compared to other groups. The most important representatives of this group are, for example, nortriptyline, amitriptyline, and clomipramine. Another group of antidepressants is selective serotonin reuptake inhibitors (SSRIs), which are among the most commonly prescribed antidepressants. The most important representatives are fluoxetine, sertraline, citalopram, and others. Other frequently prescribed types of antidepressants are serotonin and norepinephrine reuptake inhibitors (e.g., venlafaxine), which are used for the treatment of major depression, anxiety, mood disorders, etc. Compared to the other groups, they have milder side effects. Another type are antidepressants that act as reversible inhibitors of monoamine oxidases (e.g., moclobemide) [14,15,20,21].

Recently, the presence of antidepressants in fresh and marine ecosystems has increased. Therefore, it potentially poses a significant ecological risk to various non-target aquatic organisms [22-27]. Antidepressants are detected in surface waters at concentrations most often ranging in orders of magnitude from a tenth to hundreds of ng/L [14]. Higher concentrations are detected especially downstream of hospitals or in wastewater treatment plants [28,29]. Although the detected levels of these medications are relatively low, it is known that even such environmentally relevant doses can disturb the physiological functions of exposed aquatic organisms [14]. Ecotoxicological studies confirm a number of negative effects on various aquatic organisms, such as the induction of oxidative stress [25,30], embryotoxicity [31], immunotoxicity [32], developmental abnormalities [33-35], histopathological findings [32,34], etc. Many studies also point to possible abnormalities connected to reproductive functions [15]. Foran et al. [27] reported a statistically significant increase in estradiol in Japanese medaka (Oryzias latipes) females after exposure to fluoxetine at concentrations of 100 and $500 \mathrm{ng} / \mathrm{L}$ for a period of 30 days. Furthermore, Pelli and Connaughton [36] found that fluoxetine also significantly affects fish behavior, causes swimming abnormalities, and reduces the caution of fish before a potential predator attack. Similarly, Woodman et al. [37] described an increase in aggressiveness of crayfish Orconectes virilisafter after sertraline exposure. Additionally, Liu et al. [38] reported opposite outcomes, in the form of seizure susceptibility and habituation, in African clawed frogs (Xenopus laevis) after exposure to two antidepressants from the same group of these psychiatric drugs. A fluoxetine-treated group of tadpoles showed increased seizure susceptibility and reduced startel habituation, and on the other hand, a citalopram-treated group reported decreased seizure susceptibility and increased habituation.

Various representatives of aquatic organisms (e.g., fish, amphibians, invertebrates) are used in ecotoxicological tests for the evaluation of potential negative effects of tested chemicals [39-51]. The $3 R$ approach (reduce, refine, replace) is an alternative strategy, which prevents the unnecessary suffering of animals and reduces the number of tested animals [52-54]. In accordance with European legislation, the embryonic stages of aquatic organisms are not considered as experimental animals. Their undeniable advantage is that they are very sensitive to the action of various pollutants, providing relevant and reproducible results. In addition, the embryonic tests are fast and cost-effective [54].

In view of this, the aim of our study was to compare the sensitivity of the embryos of two different representatives of aquatic organisms (zebrafish and African clawed frogs) exposed to two antidepressants both as a single substance and as a mixture. Fluoxetine hydrochloride and citalopram hydrochloride acting as selective serotonin reuptake inhibitors were chosen because of their abundant use in human medicine and due to the frequent occurrence of their residues in the surface water. The evaluation was performed 
using embryonic toxicity tests, in which selected indicators of embryotoxicity (mortality, hatching, malformations, and heart rate) were monitored at regular intervals for $96 \mathrm{~h}$.

\section{Materials and Methods}

\subsection{Chemicals and Materials}

Both antidepressants (fluoxetine hydrochloride- $-\mathrm{M}_{\mathrm{r}}=345.79$, and citalopram hydrochloride $\left.-\mathrm{M}_{\mathrm{r}}=360.85\right)$ were purchased as analytical standards from Merck Life Science, s.r.o. (Czech Republic). All the tested solutions were prepared a day prior to use in standardized dilution water with $\mathrm{pH}=7.8$ [55]. Because of the sufficient solubility of both chemicals, no solvent was necessary to prepare the stock solutions. The tested concentrations of the individual antidepressants were as follows: fluoxetine hydrochloride $-0.1 ; 1 ; 10 ; 100$; 1000; and 10,000 $\mu \mathrm{g} / \mathrm{L}$; citalopram hydrochloride-0.01; 0.1; 1; 10; 100; 1000; 10,000; and $100,000 \mu \mathrm{g} / \mathrm{L}$. The lowest concentrations of the individual psychiatric drugs were chosen with respect to environmentally relevant levels in surface waters; higher doses were chosen as a multiple of the lowest dose to evaluate the concentration-dependent effect [28,56,57]. In addition, both substances were tested as a mixture at three different concentration levels: low (fluoxetine hydrochloride $0.1 \mu \mathrm{g} / \mathrm{L}$, citalopram hydrochloride $0.01 \mu \mathrm{g} / \mathrm{L}$ ), medium (fluoxetine hydrochloride $10 \mu \mathrm{g} / \mathrm{L}$, citalopram hydrochloride $1 \mu \mathrm{g} / \mathrm{L}$ ), and high (fluoxetine hydrochloride $1000 \mu \mathrm{g} / \mathrm{L}$, citalopram hydrochloride $100 \mu \mathrm{g} / \mathrm{L})$.

\subsection{Zebrafish Embryo Toxicity Test}

The embryonic toxicity tests on zebrafish (Danio rerio), a widely used fish model organism, were performed using a modified version of the Fish Embryo Acute Toxicity Test (FET) - OECD guidline 236 [58] in accreditated laboratories for laboratory animals of the Department of Animal Protection and Welfare and Veterinary Public Health (University of Veterinary Sciences Brno, Czech Republic).

The fertilized eggs were purchased from a certified commercial producer (Mendel University in Brno, Czech Republic) [1,2]. At first, the quality and stage of the zebrafish embryos were examined using a stereomicroscope. The fertilized eggs at the 16-cell stage without any obvious abnormalities were selected for the embryonic toxicity test, in which they were exposed to the individual antidepressants and to their mixtures for $96 \mathrm{~h}$. Detailed information about the tested concentrations is highlighted in Section 2.1. Chemicals and Materials. The eggs were randomly distributed on microwell plates, one embryo in each well. A total number of 36 fertilized eggs was used for each tested concentration and for the control group as well. The tested solutions were changed every $24 \mathrm{~h}$ by gently draining each well and adding a new working solution slowly to avoid any disturbance. The plates were stored in the growth chamber with constant parameters $\left(26 \pm 1{ }^{\circ} \mathrm{C}\right.$, photoperiod $12 \mathrm{~h} / 12 \mathrm{~h}$ ). The embryo monitoring was performed using a stereomicroscope at $24,48,72$, and $96 \mathrm{~h}$ post-fertilization (hpf). Next, the lethal and sublethal endpoints were recorded-mortality, hatching, the occurrence of malformations (e.g., oedema, changes in pigmentation, deformities) [59]. In addition to this, the heart rate monitoring was performed using a stereomicroscope at $48 \mathrm{hpf}$. The heart rate observations were performed manually by visual inspection and repeated three times for each embryo. The number of beats was counted for $30 \mathrm{~s}$ and the results were expressed as the number of beats per minute. The embryo monitoring was performed by experienced examiners who were blind to the treatments.

\subsection{African Clawed Frog Embryo Toxicity Test}

The African clawed frog (Xenopus laevis) was chosen as the next most suitable aquatic model organism of those frequently used in toxicological tests. The toxicity tests were performed using the Standard Guide for Conducting the Frog Embryo Teratogenesis AssayXenopus (FETAX) [60]. The experiment took place again in the accreditated laboratories of University of Veterinary Sciences Brno (Czech Republic). 
The fertilized eggs of African clawed frogs were purchased from a certified commercial producer (Masaryk University, Brno, Czech Republic). As in the previous toxicity tests on zebrafish, we checked the quality and stage of the embryos and only eggs without irregularities were used for our study. The same concentration levels and time of exposure $(96 \mathrm{~h})$ were used for the embryonic toxicity tests. The eggs were randomly distributed on microwell plates, one embryo in each well. A total of 18 fertilized eggs was used for each tested concentration and for the control as well. Replacement of the working solutions was performed daily. The plates were kept in a growth chamber with similar conditions as that used in the zebrafish toxicity test $\left(23 \pm 1{ }^{\circ} \mathrm{C}\right.$, photoperiod $\left.12 \mathrm{~h} / 12 \mathrm{~h}\right)$. The recorded endpoints were identical to those used in the embryonic toxicity tests on the zebrafish. The observations of the embryos were performed every twenty-four hours for a total of $96 \mathrm{~h}$. Only the monitoring of the heart rate was performed due to the transparence of the embryos at $56 \mathrm{hpf}$. As in the previous embryonic toxicity tests on the zebrafish, all the monitoring was performed by experienced examiners who were not informed about the treatments.

\subsection{Data Analysis}

All the endpoints were evaluated using the statistical software, Unistat for Excel 6.5. The differences between the frequencies of the monitored variables, such as mortality, hatching rate, and the incidence of malformations, were tested using the chi-square $\left(\chi^{2}\right)$ test of independence. The results were expressed as percentages and the data of the hatching rate and the occurrence of malformations were always based on the surviving embryos at a given time. For the evaluation of the heart rate, the results were tested using the Shapiro-Wilk test and the Levene test for normality and homogeneity of variances across the groups, respectively. The results of the African clawed frog heart rates were normally distributed and for this reason they were subjected to a one-way analysis of variance (ANOVA), followed by the Dunnett's post hoc test to determine the differences between the control and experimental groups. The zebrafish heart rates did not meet the assumption of normality; therefore, the Kruskal-Wallis ANOVA non-parametric test was used for further evaluation. The experimental groups were always compared to the relevant control group at the same time of exposure. The difference was considered statistically significant when $p<0.05$ or $p<0.01$.

\section{Results}

\subsection{Cumulative Mortality of Zebrafish and African Clawed Frog Embryos}

The results of the cumulative mortality of the zebrafish and African clawed frog embryos are presented in Tables 1 and 2. In the embryonic test on zebrafish, no significant differences were observed between the control and experimental groups exposed to fluoxetine hydrochloride and citalopram hydrochloride as single substances and their mixture at the same time of exposure (Table 1). No mortality was found in the control group during the embryotoxicity assay. The highest cumulative mortality $(8.3 \%)$ was found in the experimental group exposed to fluoxetine hydrochloride at $100 \mu \mathrm{g} / \mathrm{L}$ at $72 \mathrm{hpf}$. The same mortality was also observed in the experimental group exposed to the medium concentration of both antidepressants (fluoxetine hydrochloride $-10 \mu \mathrm{g} / \mathrm{L}$, citalopram hydrochloride $-1 \mu \mathrm{g} / \mathrm{L}$ ). However, this cumulative mortality was already recorded at $24 \mathrm{hpf}$. 
Table 1. Cumulative mortality (\%) of zebrafish embryos exposed to antidepressants as single substances and as a mixture. No significant differences $(p>0.05)$ were observed between the control and the experimental groups at the same time of exposure.

\begin{tabular}{cccccc}
\hline Group & Concentration & $\mathbf{2 4} \mathbf{~ h p f}$ & $\mathbf{4 8} \mathbf{~ h p f}$ & $\mathbf{7 2 ~ h p f}$ & $\mathbf{9 6} \mathbf{~ h p f}$ \\
\hline control & - & 0 & 0 & 0 & 0 \\
\hline & $0.1 \mu \mathrm{g} / \mathrm{L}$ & 0 & 0 & 0 & 0 \\
& $1 \mu \mathrm{g} / \mathrm{L}$ & 0 & 0 & 0 & 0 \\
$\mathrm{~F}$ & $10 \mu \mathrm{g} / \mathrm{L}$ & 5.6 & 5.6 & 5.6 & 5.6 \\
& $100 \mu \mathrm{g} / \mathrm{L}$ & 5.6 & 5.6 & 8.3 & 8.3 \\
& $1000 \mu \mathrm{g} / \mathrm{L}$ & 5.6 & 5.6 & 5.6 & 5.6 \\
& $10,000 \mu \mathrm{g} / \mathrm{L}$ & 5.6 & 5.6 & 5.6 & 5.6 \\
\hline \multirow{5}{*}{$\mathrm{C}$} & $0.01 \mu \mathrm{g} / \mathrm{L}$ & 0 & 0 & 0 & 2.8 \\
& $0.1 \mu \mathrm{g} / \mathrm{L}$ & 0 & 0 & 2.8 & 0 \\
& $1 \mu \mathrm{g} / \mathrm{L}$ & 0 & 0 & 0 & 2.8 \\
& $10 \mu \mathrm{g} / \mathrm{L}$ & 2.8 & 2.8 & 2.8 & 2.8 \\
& $100 \mu \mathrm{g} / \mathrm{L}$ & 2.8 & 2.8 & 0 & 0 \\
& $1000 \mu \mathrm{g} / \mathrm{L}$ & 0 & 0 & 0 & 5.6 \\
\hline \multirow{5}{*}{$\mathrm{F}+\mathrm{C}$} & $10,000 \mu \mathrm{g} / \mathrm{L}$ & 0 & 0 & 5.6 & 2.8 \\
& $100,000 \mu \mathrm{g} / \mathrm{L}$ & 5.6 & 5.6 & 2.8 & 8.3 \\
& $\mathrm{low}$ & 2.8 & 2.8 & 8.3 & 2.8 \\
\hline
\end{tabular}

Abbreviations: F-fluoxetine hydrochloride; $\mathrm{C}$-citalopram hydrochloride; hpf-hours post-fertilization; lowfluoxetine hydrochloride $0.1 \mu \mathrm{g} / \mathrm{L}$, citalopram hydrochloride $0.01 \mu \mathrm{g} / \mathrm{L}$; medium-fluoxetine hydrochloride $10 \mu \mathrm{g} / \mathrm{L}$, citalopram hydrochloride $1 \mu \mathrm{g} / \mathrm{L}$; high-fluoxetine hydrochloride $1000 \mu \mathrm{g} / \mathrm{L}$, citalopram hydrochloride $100 \mu \mathrm{g} / \mathrm{L}$.

Table 2. Cumulative mortality (\%) of African clawed frog embryos exposed to antidepressants as single substances and as a mixture. Bold font and the asterisks indicate a significant difference $\left.{ }^{*} p<0.05,{ }^{* *} p<0.01\right)$ between the control and the experimental groups at the same time of exposure.

\begin{tabular}{|c|c|c|c|c|c|}
\hline Group & Concentration & $24 \mathrm{hpf}$ & $48 \mathrm{hpf}$ & $72 \mathrm{hpf}$ & $96 \mathrm{hpf}$ \\
\hline control & - & 0 & 0 & 0 & 5.6 \\
\hline \multirow{6}{*}{$\mathrm{F}$} & $0.1 \mu \mathrm{g} / \mathrm{L}$ & 0 & 0 & 0 & 0 \\
\hline & $1 \mu \mathrm{g} / \mathrm{L}$ & 0 & 0 & 0 & 5.6 \\
\hline & $10 \mu \mathrm{g} / \mathrm{L}$ & 0 & 0 & 5.6 & 5.6 \\
\hline & $100 \mu \mathrm{g} / \mathrm{L}$ & 0 & 0 & 0 & 5.6 \\
\hline & $1000 \mu \mathrm{g} / \mathrm{L}$ & 0 & 5.6 & 5.6 & 5.6 \\
\hline & $10,000 \mu \mathrm{g} / \mathrm{L}$ & 0 & 5.6 & $100 * *$ & - \\
\hline \multirow{8}{*}{$\mathrm{C}$} & $0.01 \mu \mathrm{g} / \mathrm{L}$ & 0 & 0 & 0 & 5.6 \\
\hline & $0.1 \mu \mathrm{g} / \mathrm{L}$ & 0 & 0 & 0 & 0 \\
\hline & $1 \mu \mathrm{g} / \mathrm{L}$ & 0 & 0 & 0 & 5.6 \\
\hline & $10 \mu \mathrm{g} / \mathrm{L}$ & 0 & 0 & 0 & 0 \\
\hline & $100 \mu \mathrm{g} / \mathrm{L}$ & 0 & 0 & 5.6 & 0 \\
\hline & $1000 \mu \mathrm{g} / \mathrm{L}$ & 0 & 0 & 5.6 & 5.6 \\
\hline & $10,000 \mu \mathrm{g} / \mathrm{L}$ & 0 & 0 & 0 & 5.6 \\
\hline & $100,000 \mu \mathrm{g} / \mathrm{L}$ & 0 & 0 & $100 * *$ & - \\
\hline \multirow{3}{*}{$\mathrm{F}+\mathrm{C}$} & low & 0 & 0 & 5.6 & $44.4^{*}$ \\
\hline & medium & 0 & 5.6 & 5.6 & 11.1 \\
\hline & high & 0 & 0 & 0 & 5.6 \\
\hline
\end{tabular}

Abbreviations: F-fluoxetine hydrochloride; C—citalopram hydrochloride; hpf-hours post-fertilization; lowfluoxetine hydrochloride $0.1 \mu \mathrm{g} / \mathrm{L}$, citalopram hydrochloride $0.01 \mu \mathrm{g} / \mathrm{L} ;$ medium-fluoxetine hydrochloride $10 \mu \mathrm{g} / \mathrm{L}$, citalopram hydrochloride $1 \mu \mathrm{g} / \mathrm{L}$; high-fluoxetine hydrochloride $1000 \mu \mathrm{g} / \mathrm{L}$, citalopram hydrochloride $100 \mu \mathrm{g} / \mathrm{L}$.

By contrast, significantly higher cumulative mortality was observed in the embryonic toxicity test performed on the African clawed frogs. All the results are presented in Table 2. In this test, we also recorded mortality in the control group. However, it was only 
$5.6 \%$ at 96 hpf. A high toxic effect was found in the highest test concentrations of both antidepressants, fluoxetine hydrochloride $(10,000 \mu \mathrm{g} / \mathrm{L})$ and citalopram hydrochloride $(100,000 \mu \mathrm{g} / \mathrm{L})$, as single substances, where a $100 \%$ mortality was observed at $72 \mathrm{hpf}$. These results were significantly different to the cumulative mortality in the control group at the same time of exposure $(p<0.01)$. Surprising results were observed in the toxicity test with the mixture of antidepressants, where the highest cumulative mortality $(44.4 \%)$ with a statistically significant difference $(p<0.05)$ compared to the control group at the same time of exposure was observed in the lowest concentrations of both antidepressants (fluoxetine hydrochloride $-0.1 \mu \mathrm{g} / \mathrm{L}$ and citalopram hydrochloride $-0.01 \mu \mathrm{g} / \mathrm{L}$ ) at $96 \mathrm{hpf}$.

\subsection{Hatching Rate of Zebrafish and African Clawed Frog Embryos}

The detailed results of the hatching rate in the individual embryonic tests on zebrafish are highlighted in Figures 1-3. The first hatching was recorded at $72 \mathrm{hpf} ; 16.7 \%$ of the embryos in the control group were hatched within this observation time. In most of the experimental groups, a higher hatching rate compared to the control group was recorded at this time. At $72 \mathrm{hpf}$, statistically significant earlier hatching was found in the experimental groups exposed to fluoxetine hydrochloride at $1 \mu \mathrm{g} / \mathrm{L}$ ( $52.8 \%$ of hatched embryos, $p<0.01)$, citalopram hydrochloride at $1 \mu \mathrm{g} / \mathrm{L}(58.3 \%$ of hatched embryos, $p<0.01), 10 \mu \mathrm{g} / \mathrm{L}(54.3 \%$ of hatched embryos, $p<0.01$ ), and 100,000 $\mu \mathrm{g} / \mathrm{L}$ ( $55.9 \%$ of hatched embryos, $p<0.01$ ). Similarly, significant differences in the hatching rate compared to the control group were also observed in the embryonic test with citalopram hydrochloride and fluoxetine hydrochloride as a mixture at $72 \mathrm{hpf}$. Statistically significant $(p<0.01)$ earlier hatching was recorded in all the tested concentrations at $72 \mathrm{hpf}$. A total of $62.9,69.7$ and $65.7 \%$ of hatched embryos was found in the experimental groups exposed to the mixture of antidepressants at low, medium, and high concentrations, respectively. No significant differences in the hatching rate between the control and experimental groups were found at $96 \mathrm{hpf}$; almost all the embryos were hatched at this time.

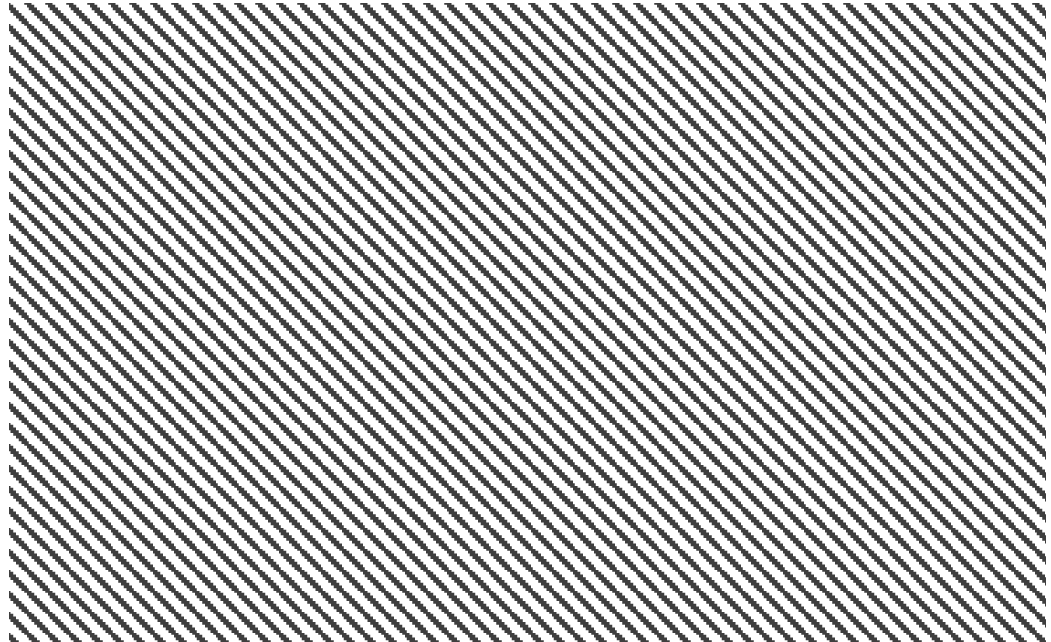

Figure 1. The hatching rate $(\%)$ of zebrafish exposed to fluoxetine hydrochloride (hpf-hours postfertilization). The asterisk indicates a significant difference $(* * p<0.01)$ between the control and the experimental groups at the same time of exposure. 


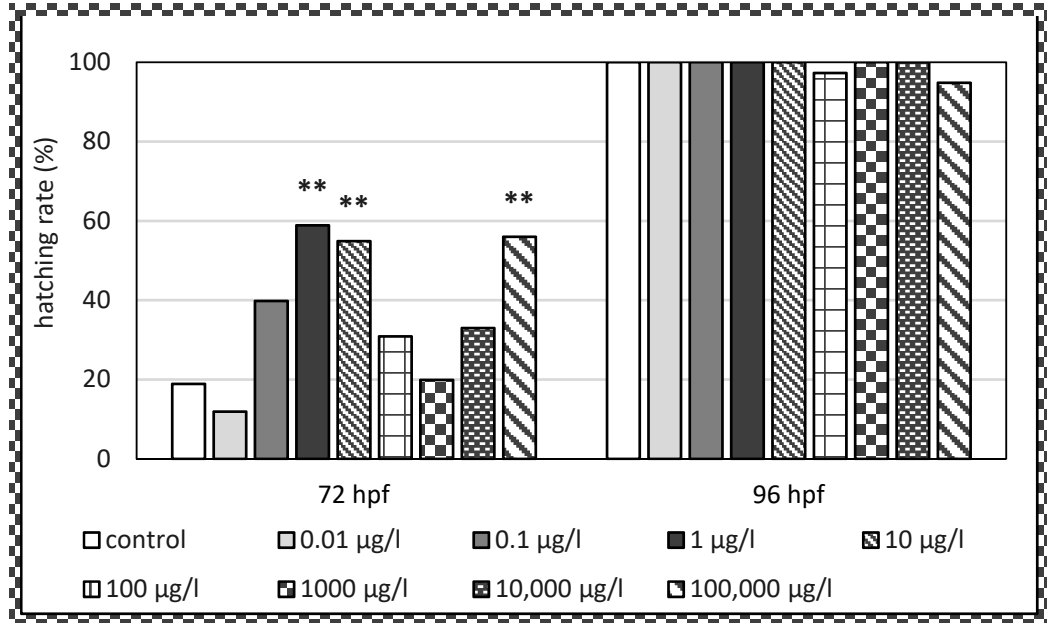

Figure 2. The hatching rate (\%) of zebrafish exposed to citalopram hydrochloride (hpf-hours postfertilization). The asterisk indicates a significant difference $(* *<<0.01)$ between the control and the experimental groups at the same time of exposure.

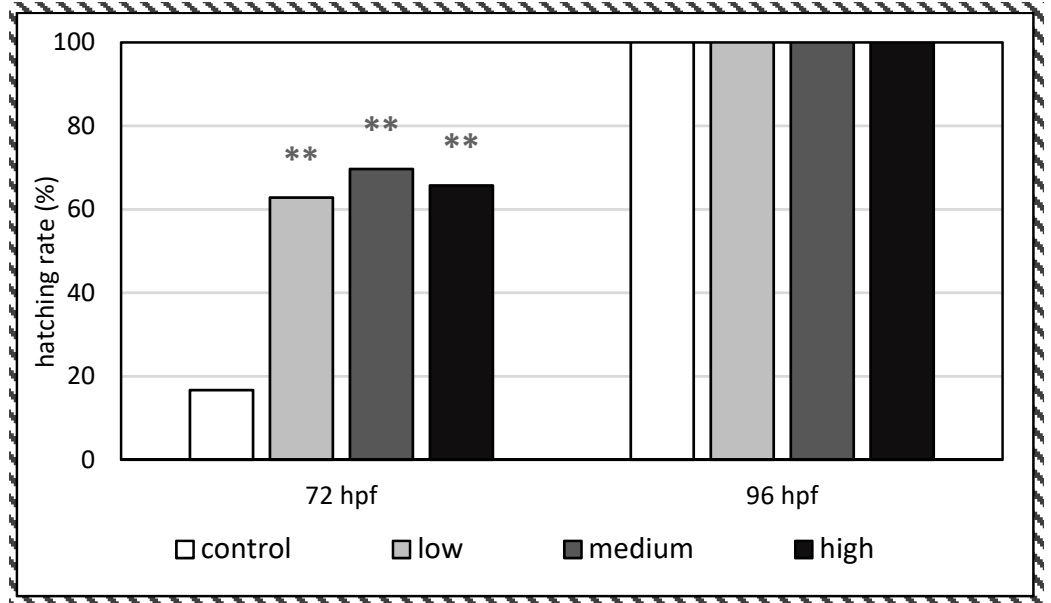

Figure 3. The hatching rate (\%) of zebrafish exposed to the mixture of antidepressants. The asterisk indicates a significant difference $\left.{ }^{* *} p<0.01\right)$ between the control and the experimental groups at the same time of exposure. (hpf-hours post fertilization; low-fluoxetine hydrochloride $0.1 \mu \mathrm{g} / \mathrm{L}$, citalopram hydrochloride $0.01 \mu \mathrm{g} / \mathrm{L}$; medium-fluoxetine hydrochloride $10 \mu \mathrm{g} / \mathrm{L}$, citalopram hydrochloride $1 \mu \mathrm{g} / \mathrm{L}$; high—fluoxetine hydrochloride $1000 \mu \mathrm{g} / \mathrm{L}$, citalopram hydrochloride $100 \mu \mathrm{g} / \mathrm{L}$ ).

In the embryonic test on the African clawed frogs, the first hatching was already recorded at $48 \mathrm{hpf}$ (data not shown). At this time, all the embryos in the control group were hatched. Similarly, most embryos in the experimental groups finished their hatching in this time with the exception of the experimental groups exposed to citalopram hydrochloride at $0.1 \mu \mathrm{g} / \mathrm{L}$ and $10,000 \mu \mathrm{g} / \mathrm{L}$ (only $88.9 \%$ of hatched embryos) and fluoxetine hydrochloride at $1 \mu \mathrm{g} / \mathrm{L}$ (only $94.4 \%$ of hatched embryos). However, the statistical analysis did not reveal any significant differences $(p>0.05)$ in the hatching rate between the control and experimental groups at the same time of exposure.

\subsection{Embryonic Malformations in Zebrafish and African Clawed Frog}

The observation of malformations offered valuable information about the various toxic effects of the tested substances. The most common findings of malformations in the embryonic toxicity tests were abnormalities in pigmentation (reduced or increased), various types of oedema (e.g., pericardial oedema, yolk sac oedema), and developmental malformations of the tail, eye, head, or the whole body. Representative images of some malformations obtained in our embryonic tests on the zebrafish and African clawed frog 
embryos are presented in Figure 4. The results of the relative malformations in the embryos exposed to antidepressants as single substances or as a mixture are summarized in Table 3 (for zebrafish) and Table 4 (for the African clawed frog). The results are related only to living individuals and are expressed as a sum of all the malformation effects.

In general, we found a lower incidence of malformations in the embryonic tests using zebrafish as the model organism. No malformations were observed in the control group. The highest incidence of malformations was recorded in the experimental groups exposed to the antidepressant fluoxetine hydrochloride, especially in the two highest concentrations $(1000 \mu \mathrm{g} / \mathrm{L}$ and 10,000 $\mu \mathrm{g} / \mathrm{L})$. At both concentrations, the occurrence of malformations was tested as significant compared to the control group at $72 \mathrm{hpf}$ and $96 \mathrm{hpf}$. We recorded the following malformations: deformities of the spine and tail (especially bending of the tail), and oedema of the heart and yolk sac. The highest incidence was observed in the experimental group exposed to $10,000 \mu \mathrm{g} / \mathrm{L}$ at $96 \mathrm{hpf}$ (41.2 of living embryos, $p<0.01$ ). In the embryonic toxicity test with citalopram hydrochloride, a statistically significant difference $(p<0.05)$ compared to the control group was recorded only at the highest concentration of the antidepressant $(100,000 \mu \mathrm{g} / \mathrm{L})$, at $96 \mathrm{hpf}$ (17.6\% of living embryos). Oedema of the heart and body deformations were recorded. In the embryonic test evaluating the effects of a combination of both antidepressants, a statistically significant difference $(p<0.05)$ compared to the control group was found only at the medium concentration of the drugs (fluoxetine hydrochloride $-10 \mu \mathrm{g} / \mathrm{L}$, citalopram hydrochloride $-1 \mu \mathrm{g} / \mathrm{L}$ ) at $96 \mathrm{hpf}$. In this experimental group, yolk sac oedema was recorded in $18.2 \%$ of the living embryos.

Table 3. Malformations (\%) in zebrafish embryos exposed to antidepressants as single substances and as a mixture. The results are related only to living individuals. Bold font and asterisks indicate a significant difference $\left({ }^{*} p<0.05,{ }^{* *} p<0.01\right)$ between the control and the experimental groups at the same time of exposure.

\begin{tabular}{|c|c|c|c|c|c|}
\hline Group & Concentration & $24 \mathrm{hpf}$ & $48 \mathrm{hpf}$ & $72 \mathrm{hpf}$ & $96 \mathrm{hpf}$ \\
\hline control & - & 0 & 0 & 0 & 0 \\
\hline \multirow{6}{*}{$\mathrm{F}$} & $0.1 \mu \mathrm{g} / \mathrm{L}$ & 0 & 0 & 11.1 & 0 \\
\hline & $1 \mu \mathrm{g} / \mathrm{L}$ & 0 & 0 & 0 & 0 \\
\hline & $10 \mu \mathrm{g} / \mathrm{L}$ & 0 & 2.9 & 11.8 & 2.9 \\
\hline & $100 \mu \mathrm{g} / \mathrm{L}$ & 2.9 & 11.8 & 12.1 & 9.1 \\
\hline & $1000 \mu \mathrm{g} / \mathrm{L}$ & 0 & 0 & $26.5 *$ & $26.5 *$ \\
\hline & $10,000 \mu \mathrm{g} / \mathrm{L}$ & 5.9 & 5.9 & $23.5 *$ & $41.2 * *$ \\
\hline \multirow{8}{*}{$\mathrm{C}$} & $0.01 \mu \mathrm{g} / \mathrm{L}$ & 0 & 2.9 & 0 & 0 \\
\hline & $0.1 \mu \mathrm{g} / \mathrm{L}$ & 0 & 2.7 & 8.6 & 2.9 \\
\hline & $1 \mu \mathrm{g} / \mathrm{L}$ & 0 & 0 & 0 & 2.8 \\
\hline & $10 \mu \mathrm{g} / \mathrm{L}$ & 0 & 2.9 & 0 & 0 \\
\hline & $100 \mu \mathrm{g} / \mathrm{L}$ & 0 & 2.9 & 2.9 & 14.3 \\
\hline & $1000 \mu \mathrm{g} / \mathrm{L}$ & 0 & 0 & 0 & 2.8 \\
\hline & $10,000 \mu \mathrm{g} / \mathrm{L}$ & 0 & 2.8 & 5.6 & 2.8 \\
\hline & $100,000 \mu \mathrm{g} / \mathrm{L}$ & 3.0 & 5.9 & 2.9 & 17.6 * \\
\hline \multirow{3}{*}{$F+C$} & low & 0 & 2.9 & 11.4 & 5.7 \\
\hline & medium & 0 & 0 & 0 & $18.2 *$ \\
\hline & high & 0 & 0 & 14.3 & 2.9 \\
\hline
\end{tabular}

Abbreviations: F-fluoxetine hydrochloride; $\mathrm{C}$-citalopram hydrochloride; hpf-hours post-fertilization; lowfluoxetine hydrochloride $0.1 \mu \mathrm{g} / \mathrm{L}$, citalopram hydrochloride $0.01 \mu \mathrm{g} / \mathrm{L}$; medium-fluoxetine hydrochloride $10 \mu \mathrm{g} / \mathrm{L}$, citalopram hydrochloride $1 \mu \mathrm{g} / \mathrm{L}$; high-fluoxetine hydrochloride $1000 \mu \mathrm{g} / \mathrm{L}$, citalopram hydrochloride $100 \mu \mathrm{g} / \mathrm{L}$. 

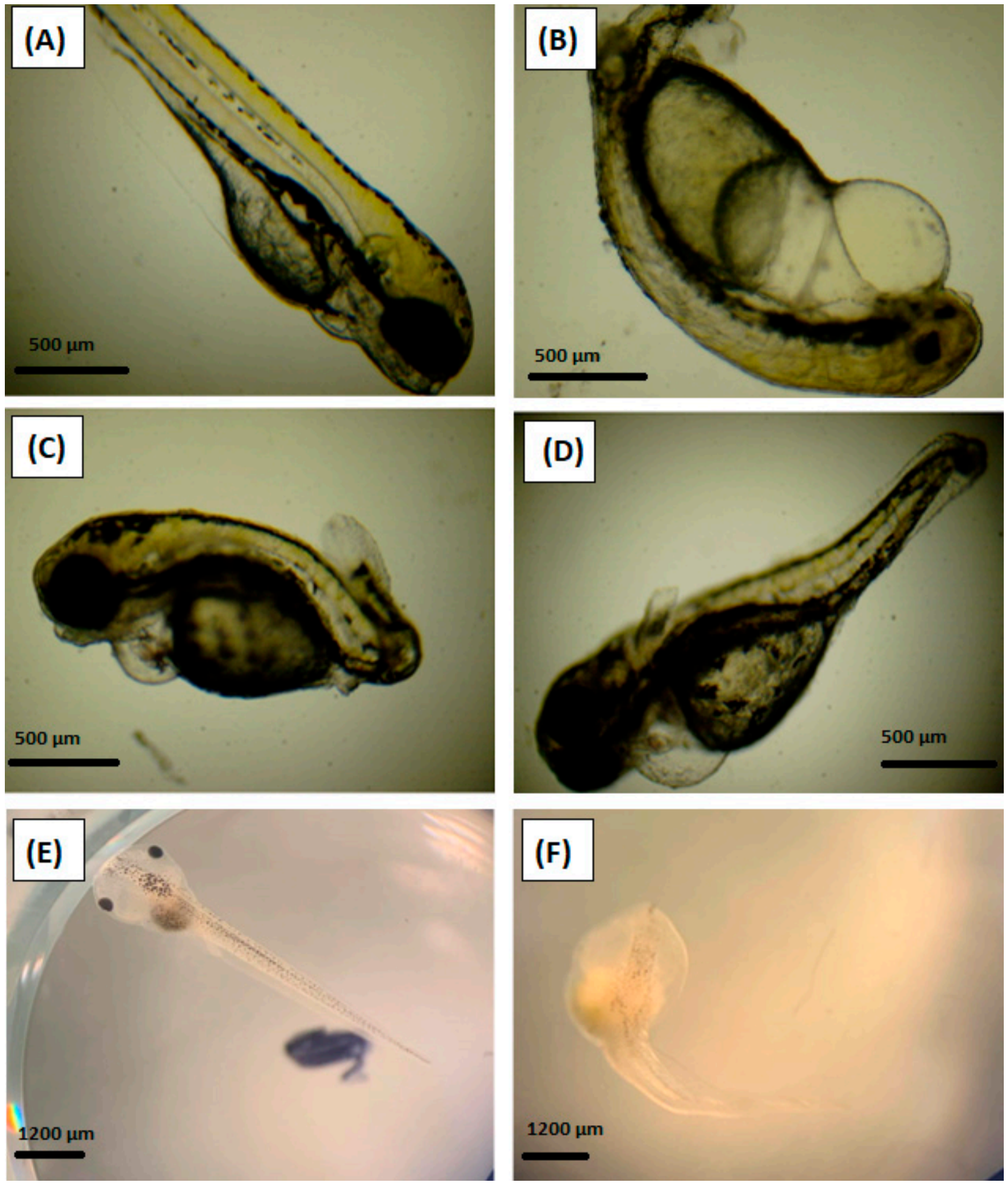

Figure 4. (A) Hatched zebrafish embryo in the control group at $96 \mathrm{~h}$ post-fertilization; (B) malformation of zebrafish embryo (oedema of heart and yolk sac, total body deformation) in the experimental group exposed to 10,000 $\mu \mathrm{g} / \mathrm{L}$ of fluoxetine hydrochloride at $72 \mathrm{~h}$ post-fertilization; (C) malformation of zebrafish embryo (body deformation, pericardial oedema) in the experimental group exposed to $10,000 \mu \mathrm{g} / \mathrm{L}$ of fluoxetine hydrochloride at $96 \mathrm{~h}$ post-fertilization; (D) malformation of zebrafish embryo (body deformation, pericardial oedema) in the experimental group exposed to 100,000 $\mu \mathrm{g} / \mathrm{L}$ of citalopram hydrochloride at $96 \mathrm{~h}$ post-fertilization; (E) African clawed frog embryo in the control group at $72 \mathrm{~h}$ post-fertilization; (F) malformation of African clawed frog embryo (total body deformation) in the experimental group exposed to $1000 \mu \mathrm{g} / \mathrm{L}$ of fluoxetine hydrochloride at $72 \mathrm{~h}$ post-fertilization. 
Table 4. Malformations (\%) in African clawed frog embryos exposed to antidepressants as single substances and as a mixture. The results are related only to living individuals. Bold font and asterisks indicate a significant difference $\left({ }^{*} p<0.05\right)$ between the control and the experimental groups at the same time of exposure.

\begin{tabular}{|c|c|c|c|c|c|}
\hline Group & Concentration & $24 \mathrm{hpf}$ & $48 \mathrm{hpf}$ & $72 \mathrm{hpf}$ & $96 \mathrm{hpf}$ \\
\hline control & - & 0 & 5.6 & 11.1 & 11.8 \\
\hline \multirow{6}{*}{ F } & $0.1 \mu \mathrm{g} / \mathrm{L}$ & 0 & 0 & 11.1 & 33.3 \\
\hline & $1 \mu \mathrm{g} / \mathrm{L}$ & 0 & 22.2 & 22.2 & 23.5 \\
\hline & $10 \mu \mathrm{g} / \mathrm{L}$ & 0 & 16.7 & 17.6 & 23.5 \\
\hline & $100 \mu \mathrm{g} / \mathrm{L}$ & 0 & 11.1 & 11.1 & 11.8 \\
\hline & $1000 \mu \mathrm{g} / \mathrm{L}$ & 0 & 17.6 & 29.4 & $41.2 *$ \\
\hline & $10,000 \mu \mathrm{g} / \mathrm{L}$ & 0 & 5.9 & - & - \\
\hline \multirow{8}{*}{$\mathrm{C}$} & $0.01 \mu \mathrm{g} / \mathrm{L}$ & 0 & 0 & 27.8 & 27.8 \\
\hline & $0.1 \mu \mathrm{g} / \mathrm{L}$ & 0 & 16.7 & 22.2 & 23.5 \\
\hline & $1 \mu \mathrm{g} / \mathrm{L}$ & 0 & 11.1 & 11.1 & 5.6 \\
\hline & $10 \mu \mathrm{g} / \mathrm{L}$ & 0 & 11.1 & 16.7 & 16.7 \\
\hline & $100 \mu \mathrm{g} / \mathrm{L}$ & 0 & 22.2 & 32.3 & $52.3 *$ \\
\hline & $1000 \mu \mathrm{g} / \mathrm{L}$ & 0 & 16.7 & 17.6 & 23.5 \\
\hline & $10,000 \mu \mathrm{g} / \mathrm{L}$ & 0 & 16.7 & 16.7 & 17.6 \\
\hline & $100,000 \mu \mathrm{g} / \mathrm{L}$ & 0 & 22.2 & - & - \\
\hline \multirow{3}{*}{$\mathrm{F}+\mathrm{C}$} & low & 0 & 0 & $41.2 *$ & $50.0 *$ \\
\hline & medium & 0 & 5.9 & 29.4 & 31.3 \\
\hline & high & 0 & 5.6 & 16.7 & 17.6 \\
\hline
\end{tabular}

Abbreviations: F-fluoxetine hydrochloride; C-citalopram hydrochloride; hpf-hours post-fertilization; lowfluoxetine hydrochloride $0.1 \mu \mathrm{g} / \mathrm{L}$, citalopram hydrochloride $0.01 \mu \mathrm{g} / \mathrm{L} ;$ medium-fluoxetine hydrochloride $10 \mu \mathrm{g} / \mathrm{L}$, citalopram hydrochloride $1 \mu \mathrm{g} / \mathrm{L}$; high-fluoxetine hydrochloride $1000 \mu \mathrm{g} / \mathrm{L}$, citalopram hydrochloride $100 \mu \mathrm{g} / \mathrm{L}$.

The incidence of malformations was significantly higher in the embryonic toxicity test on the African clawed frogs. Compared to the embryonic toxicity test on the zebrafish, malformations such as deformities of the spine and heart oedema were recorded in the control group ( $11.8 \%$ of living embryos at both $72 \mathrm{hpf}$ and $96 \mathrm{hpf}$ ). Fluoxetine hydrochloride caused a significant increase in the incidence of malformations (especially oedema of the heart and yolk sac, deformities of the tail, spine, and eye, and increased pigmentation) compared to the control group in the experimental group exposed to $1000 \mu \mathrm{g} / \mathrm{L}$ at $96 \mathrm{hpf}$ (41.2\% of living embryos, $p<0.05)$. A statistically significant difference was also observed in the embryonic toxicity test with citalopram hydrochloride. The experimental group exposed to $100 \mu \mathrm{g} / \mathrm{L}$ reported the occurrence of various malformations, such as deformities of the spine and tail, and oedema of the heart, in $52.3 \%$ of the living embryos at $96 \mathrm{hpf}$ $(p<0.05)$. Further, the combination of both antidepressants at the low concentration (fluoxetine hydrochloride $-0.1 \mu \mathrm{g} / \mathrm{L}$, citalopram hydrochloride $-0.01 \mu \mathrm{g} / \mathrm{L}$ ) caused a significant increase $(p<0.05)$ in the incidence of malformations as well. A total of $41.2 \%$ and $50 \%$ of the living embryos showed some abnormalities at $72 \mathrm{hpf}$ and $96 \mathrm{hpf}$, respectively. The most common malformations were yolk sac oedema, spinal deformity, and body shortening.

\subsection{Embryonic Heart Rate of Zebrafish and African Clawed Frog}

The results of the embryonic heart rate as another sublethal endpoint are highlighted in Table 5. The most significant changes were observed in the embryonic toxicity test on the zebrafish, especially in the tests with fluoxetine hydrochloride and a combination of both antidepressants. 
Table 5. Embryonic heart rate (beats per minute-bpm) of zebrafish (Danio rerio) and African clawed frog (Xenopus laevis) embryos exposed to antidepressants as single substances and as a mixture. The results are expressed as mean \pm standard deviation. Bold font and asterisks indicate a significant difference $\left({ }^{*} p<0.05,{ }^{* *} p<0.01\right)$ between the control and experimental groups at the same time of exposure.

\begin{tabular}{|c|c|c|c|}
\hline Group & Concentration & Danio rerio (48 hpf) & Xenopus laevis (56 hpf) \\
\hline control & - & $158.3 \pm 14.6$ & $120.0 \pm 7.4$ \\
\hline \multirow{6}{*}{$\mathrm{F}$} & $0.1 \mu \mathrm{g} / \mathrm{L}$ & $175.0 \pm 14.1 * *$ & $119.9 \pm 11.0$ \\
\hline & $1 \mu \mathrm{g} / \mathrm{L}$ & $176.4 \pm 12.6 * *$ & $121.7 \pm 6.9$ \\
\hline & $10 \mu \mathrm{g} / \mathrm{L}$ & $175.9 \pm 16.1 * *$ & $124.9 \pm 5.7$ \\
\hline & $100 \mu \mathrm{g} / \mathrm{L}$ & $173.3 \pm 17.0 * *$ & $119.7 \pm 6.2$ \\
\hline & $1000 \mu \mathrm{g} / \mathrm{L}$ & $181.1 \pm 14.1 * *$ & $123.5 \pm 12.4$ \\
\hline & $10,000 \mu \mathrm{g} / \mathrm{L}$ & $155.1 \pm 25.7$ & - \\
\hline \multirow{8}{*}{$\mathrm{C}$} & $0.01 \mu \mathrm{g} / \mathrm{L}$ & $155.8 \pm 9.4$ & $122.1 \pm 9.7$ \\
\hline & $0.1 \mu \mathrm{g} / \mathrm{L}$ & $157.0 \pm 10.9$ & $124.0 \pm 9.6$ \\
\hline & $1 \mu \mathrm{g} / \mathrm{L}$ & $157.4 \pm 9.4$ & $130.1 \pm 5.6 *$ \\
\hline & $10 \mu \mathrm{g} / \mathrm{L}$ & $157.7 \pm 10.6$ & $126.3 \pm 10.0$ \\
\hline & $100 \mu \mathrm{g} / \mathrm{L}$ & $164.2 \pm 10.2$ & $120.7 \pm 8.4$ \\
\hline & $1000 \mu \mathrm{g} / \mathrm{L}$ & $174.9 \pm 15.7^{* *}$ & $124.3 \pm 8.3$ \\
\hline & $10,000 \mu \mathrm{g} / \mathrm{L}$ & $179.2 \pm 12.5 * *$ & $112.7 \pm 7.5$ \\
\hline & $100,000 \mu \mathrm{g} / \mathrm{L}$ & $140.3 \pm 10.3$ & - \\
\hline \multirow{3}{*}{$\mathrm{F}+\mathrm{C}$} & low & $182.3 \pm 14.2 * *$ & $118.1 \pm 6.2$ \\
\hline & medium & $186.6 \pm 11.8 * *$ & $120.0 \pm 8.5$ \\
\hline & high & $180.0 \pm 14.1 * *$ & $122.6 \pm 9.5$ \\
\hline
\end{tabular}

Abbreviations: F-fluoxetine hydrochloride; $\mathrm{C}$-citalopram hydrochloride; hpf-hours post-fertilization; lowfluoxetine hydrochloride $0.1 \mu \mathrm{g} / \mathrm{L}$, citalopram hydrochloride $0.01 \mu \mathrm{g} / \mathrm{L}$; medium-fluoxetine hydrochloride $10 \mu \mathrm{g} / \mathrm{L}$, citalopram hydrochloride $1 \mu \mathrm{g} / \mathrm{L}$; high-fluoxetine hydrochloride $1000 \mu \mathrm{g} / \mathrm{L}$, citalopram hydrochloride $100 \mu \mathrm{g} / \mathrm{L} ; \mathrm{hpf}$-hours post-fertilization.

Almost all the tested concentrations of fluoxetine hydrochloride resulted in a highly significant increase in the heart rate of more than $10 \%$ compared to the control group $(p<0.01)$. Surprisingly, this significant increase was also observed in the experimental group exposed to an environmentally relevant concentration of fluoxetine hydrochloride. The exception was only the experimental group exposed to the highest concentration; the heart rate decreased in this group, but non-significantly. A significant increase in heart rate was found also in the experimental groups exposed to citalopram hydrochloride, but only at concentrations of $1000 \mu \mathrm{g} / \mathrm{L}$ and $10,000 \mu \mathrm{g} / \mathrm{L}(p<0.01)$. All the experimental groups exposed to a mixture of both antidepressants reported highly significant $(p<0.01)$ increases in heart rate, of more than $15 \%$.

Rare changes in heart rate were recorded in the toxicity test on the African clawed frog embryos. A significant increase in heart rate $(p<0.05)$ compared to the control group was found in only the experimental group exposed to citalopram hydrochloride at $1 \mu \mathrm{g} / \mathrm{L}$.

\section{Discussion}

A wide range of pharmaceuticals are continuously released into the aquatic ecosystem and subsequently detected in matrices such as water, sediment, or biota [61-66]. They appear in the aquatic environment as parent substances or their metabolites, mainly via effluent water, after their incomplete removal by wastewater treatment plants [67]. Throughout the developed world, antidepressants are an important and widely prescribed class of drugs [14]. Recently reported data show that these pharmaceuticals, even at relatively low, detectable but environmentally relevant concentrations, can significantly affect the physiological functions of various non-target aquatic organisms at different trophic levels. Importantly, aquatic organisms are exposed to these doses throughout their lifetime. These concentrations usually do not cause mortality but they can induce a number of sublethal effects that are often passed on to future generations of organisms and can affect 
fundamental ecological processes [12,68-70]. Many ecotoxicological studies also confirmed the sensitivity of various aquatic organisms to different antidepressants. For example, Ziegler et al. [71] reported that venlafaxine can affect snails (Planorbarius corneus) at levels ten times lower than citalopram.

In recent years, we have increasingly encountered the use of embryonic stages of various aquatic organisms in $t$ toxicity tests. Embryotoxicity is evaluated through the monitoring of traditional endpoints (e.g., mortality, hatching rate, malformations). In addition, endpoints such as monitoring of the heart rate and behavioral changes, or analyses of selected biomarkers (e.g., indicators of oxidative stress, gene expression), are recorded for comprehensive evaluation $[24,25,35,58]$. Lammer et al. [72] carried out a comparative evaluation of fish acute toxicity tests and embryonic toxicity tests for 143 different substances. They concluded that these embryonic toxicity tests are a potential alternative to classic acute toxicity tests and provide strong scientific results. Further, Poi et al. [73] studied the toxicity of five different antidepressant drugs on embryo-larval development and metamorphosis success in the Pacific oyster. They reported that embryotoxicity tests were more sensitive than the metamorphosis bioassay for most of the molecules tested. Moreover, embryonic toxicity tests also offer great technical benefits, such as their short duration and lower financial costs, and their requirement of a smaller volume of tested solutions. Finally, yet importantly, embryos are not considered experimental animals according to European legislation.

Although a cocktail of pollutants is present in the aquatic ecosystem, only limited ecotoxicological studies deal with combined toxicity. From this point of view, the aim of the present study was to evaluate the embryotoxicity of two frequently used antidepressants (fluoxetine hydrochloride and citalopram hydrochloride) as both single substances and as a mixture. Additionally, we compared the sensitivity of two aquatic species embryoszebrafish, as a model of fish organisms, and the African clawed frog, as a model of amphibian organisms.

Mortality is one of the traditional endpoints of toxicity studies and its monitoring is usually carried out in all types of toxicity tests, whether acute or chronic toxicity, and using different stages of tested individuals (e.g., embryo, larvae, juvenile, adult). In general, the mortality risk is very low or close to zero for environmentally relevant doses of tested chemicals. On the other hand, the toxicity of these low doses can be manifested by other sublethal endpoints, especially after chronic exposure. In our research, the zebrafish embryos were much more resistant to the tested antidepressants than the embryos of the African clawed frog and survived the exposure to concentrations many times higher than the environmentally relevant levels. No significant differences were observed between the cumulative mortality of the zebrafish embryos in all the experimental groups and to the relevant control group at the same time of exposure. By contrast, a $100 \%$ mortality of African clawed frog embryos was recorded in the highest tested concentrations of both antidepressants as single substances at 72 hpf. Similarly, Sehonova et al. [23] studied the effects of tricyclic antidepressants (amitriptyline, nortriptyline, clomipramine) on the embryo-larval developmental stages of the common carp (Cyprinus carpio). The combination of all three antidepressants at the highest tested concentration $(500 \mu \mathrm{g} / \mathrm{L})$ caused a $100 \%$ cumulative mortality at 6 days post-fertilization. A cumulative mortality of almost $100 \%$ was also found at the same concentration in the experimental groups exposed to amitriptyline and clomipramine as single substances, but at 8 and 9 days post-fertilization, respectively. The authors reported that the cardiotoxicity of these types of antidepressants seemed to be the main reason for the higher mortality. Furthermore, a statistically significant increase in the cumulative mortality of zebrafish embryos was also observed in a similar study, in which the embryotoxicity of amitriptyline was evaluated. A total of $47 \%$ of dead embryos was found in an experimental group exposed to $3000 \mu \mathrm{g} / \mathrm{L}$. In contrast to our study, the authors observed no significant differences in cumulative mortality in the toxicity test on amphibian Western clawed frog (Xenopus tropicalis) embryos after amitriptyline exposure [24]. Furthermore, de Farias et al. [32] investigated the effects of fluoxetine 
on the embryonic development of zebrafish embryos and observed $100 \%$ mortality after exposure to $5.51 \mathrm{mg} / \mathrm{L}$ and $15 \mathrm{mg} / \mathrm{L}$ at $120 \mathrm{hpf}$ and $96 \mathrm{hpf}$, respectively. Fluoxetine also significantly affected swimming activity, with a significant reduction in swimming distance. This may have been related to possible neurotoxic effects, which was also suggested by a statistically significant reduction in acetylcholinesterase activity in the treated groups.

Hatching is a critical period in embryo development and, therefore, its monitoring is an important indicator of embryotoxicity. Accelerated hatching of embryos is described in many toxicological studies after exposure to pharmaceuticals [23,74], pesticides [1,2], or emerging pollutants [3]. It can be caused by the increased spontaneous movements of treated embryos. In our study, significantly earlier hatching was found only in the zebrafish toxicity test, especially in the experimental groups exposed to the mixture of both antidepressants. No changes were recorded in the toxicity test on frog embryos, because hatching started earlier and most of the embryos were hatched at $48 \mathrm{hpf}$. Earlier hatching after antidepressant exposure has also been confirmed in some other toxicological studies. Sehonova et al. [23] reported that tricyclic antidepressants tested at a concentration range of $10 \mu \mathrm{g} / \mathrm{L}$ to $500 \mu \mathrm{g} / \mathrm{L}$ caused a statistically significantly earlier hatching of common carp embryos at both $72 \mathrm{hpf}$ and $96 \mathrm{hpf}$. However, they observed retarded development of larvae in these experimental groups over the following days of tests. Hatching stimulation of zebrafish embryos was also observed after exposure to environmentally relevant concentrations of fluoxetine by Nowakowska et al. [34]. Similarly, Kalichak [4] reported earlier hatching $(p<0.05)$ of zebrafish embryos in the experimental group exposed to fluoxetine at $0.99 \mu \mathrm{g} / \mathrm{L}$ at both $49 \mathrm{hpf}$ and $57 \mathrm{hpf}$. The authors also found that fluoxetine exposure significantly affected the larvae survival rates and increased the total length of the larvae. By contrast, different results were found in a study by de Farias et al. [34], who found delayed development $(p<0.05)$ of zebrafish embryos exposed to fluoxetine at a concentration of $15 \mathrm{mg} / \mathrm{L}$ at $48 \mathrm{hpf}$. Similarly, Poi et al. [73] reported that antidepressants such as fluoxetine, sertraline, clomipramine, amitriptyline, and duloxetine exhibited concentrationdependent effects on the embryo-larval development of Pacific oysters, characterized by a decrease in the rate of normal development. This significant impact was recorded at concentrations of $100 \mu \mathrm{g} / \mathrm{L}$ and over.

The monitoring of morphological malformations belongs to the basic observations during embryonic toxicity testing and it is described in various aquatic organisms after antidepressant exposure [24,38,72,75]. Some toxicological studies reported these anomalies even at environmentally relevant concentrations [73,74]. Nowakowska et al. [34] reported numerous malformations in the trunk or tail regions, including spinal curvatures, of zebrafish embryos after fluoxetine exposure, which may have been caused by the disturbance of nervous system development. Similarly, we found frequent tail and trunk deformities in zebrafish after fluoxetine exposure. Significant differences were confirmed in the two highest tested concentrations (1000 and 10,000 $\mu \mathrm{g} / \mathrm{L})$. Suprisingly, the combination of both antidepressants at the lowest concentrations caused the highest incidence of malformations in frog embryos. These paradoxical findings may suggest a possible combined effect of the tested substances, which is not yet described in research and could be a topic for further research. Sehonova et al. [24] tested the embryotoxicity of three antidepressants with different modes of action on the early life stages of zebrafish and the Western clawed frog. A significant increase in the incidence of malformations (oedema and developmental deformities) was demonstrated only at the highest tested concentration of amitriptyline $(3000 \mu \mathrm{g} / \mathrm{L})$ in zebrafish. However, the authors observed that even the environmentally relevant concentrations of venlafaxine and sertraline adversely affected the expression of genes closely related to the development of the heart, eyes, brain, and bones, especially in the zebrafish. By contrast, Oliveira et al. [76] documented no significant differences in any developmental formation in the early life stages of zebrafish after nortriptyline exposure (500 to $46,900 \mu \mathrm{g} / \mathrm{L}$ ).

Developmental toxicity connected with cardiac toxicity can be evaluated using a simple assay, such as the measurement of heart rate variability. Cardiotoxicity is one 
of the main adverse effects described by exposure to tricyclic antidepressants [77-79]. A critical point of heart rate monitoring is the time of observation. In published research, we can find a number of studies focused on monitoring of the cardiac rhythm in aquatic organisms after exposure to antidepressants. The reported results are often very varied and they are dependent on many parameters, such as the tested substances and their concentrations, animal species, age, sex, etc. [24,73]. In our study, we observed the most significant changes in the toxicity tests on the zebrafish. All the tested concentrations of the antidepressant mixture and fluoxetine hydrochloride (with the exception of 10,000 $\mu \mathrm{g} / \mathrm{L}$ ) as a single substance caused a highly significant increase in the heart rates of the zebrafish. In addition, a heart rate increase was also observed in two experimental groups of zebrafish embryos exposed to citalopram hydrochloride at 1000 and 10,000 $\mu \mathrm{g} / \mathrm{L}$. In contrast to our study, Kalichak et al. [4] observed a decrease in the heart rates of zebrafish embryos after exposure to $99 \mu \mathrm{g} / \mathrm{L}$ of fluoxetine $(p<0.05)$ at $49 \mathrm{hpf}$. Similarly, Sehonova et al. [24] reported a significant decrease in heart rate in both zebrafish and Western clawed frog embryos after amitriptyline exposure at a concentration of $3000 \mu \mathrm{g} / \mathrm{L}$. They also found an alteration in the mRNA expression of genes related to the heart. No significant changes in the heart rates of zebrafish embryos were described after citalopram exposure in a concentration range between $30-8000 \mu \mathrm{g} / \mathrm{L}$ at $48 \mathrm{hpf}$ [80]. This finding is partially inconsistent with our study. We noticed non-significant changes in the heart rates of the zebrafish embryos after exposure to citalopram hydrochloride at low concentrations $(0.01-100 \mu \mathrm{g} / \mathrm{L})$, but higher doses (1000 and 10,000 $\mu \mathrm{g} / \mathrm{L}$ ) resulted in a significant increase, of more than $15 \%$, compared to the control. The variation in heart rate after antidepressant exposure can be connected to the physiological response to stressful situations.

\section{Conclusions}

Based on our findings, it is clear that serotonin reuptake inhibitor antidepressants, fluoxetine hydrochloride and citalopram hydrochloride, affected the initial development of zebrafish, even at environmentally relevant concentrations. This has significant environmental implications connected to fitness reduction. Earlier hatching and an increase in heart rate were recorded in the experimental group of zebrafish embryos exposed to a mixture of both psychiatric drugs at concentrations $0.01 \mu \mathrm{g} / \mathrm{L}$ for citalopram hydrochloride and 0.1 for fluoxetine hydrochloride $(p<0.01)$. Moreover, the lowest tested concentration of fluoxetine hydrochloride $(0.1 \mu \mathrm{g} / \mathrm{L})$ resulted in a significant increase in the heart rate as well $(p<0.01)$. Moreover, the African clawed frog appears to be even more sensitive to the tested antidepressants, because the highest tested concentrations of both fluoxetine hydrochloride $(10,000 \mu \mathrm{g} / \mathrm{L})$ and citalopram hydrochloride $(100,000 \mu \mathrm{g} / \mathrm{L})$ caused a $100 \%$ mortality of the tested embryos at $72 \mathrm{hpf}$. Furthermore, it would be appropriate to carry out chronic exposures that would simulate conditions in the real environment, where aquatic organisms are exposed to pollutants throughout their lifetime. Consequently, it would also be possible to evaluate the effects on various developmental stages, from embryos to adults. Since we observed significant changes in selected indicators in environmentally realistic concentrations, it is also important to study the possible negative effects of even lower concentrations.

Author Contributions: J.B.—original draft preparation, statistical analysis, investigation; V.D.design of experiment, investigation; L.P.-investigation, original draft preparation; P.L. —methodology, investigation; D.M.-investigation; V.V.- supervision, Z.S. and C.F.-review and editing. All authors have read and agreed to the published version of the manuscript.

Funding: This scientific work was financially supported by internal grant of University of Veterinary Sciences Brno (Czech Republic)-FVHE/VEČEREK/ITA 2020.

Institutional Review Board Statement: Not applicable.

Informed Consent Statement: Not applicable. 
Data Availability Statement: The data used in this study are available on request from the corresponding author.

Acknowledgments: The authors express their deep appreciation to Eva Trnkova for manuscript improvement and for language editing. The authors also thank Martin Klein and Jana Vrablova for laboratory work and technical support during toxicity tests on zebrafish and African clawed frog embryos.

Conflicts of Interest: The authors declare no conflict of interest.

\section{References}

1. Blahova, J.; Cocilovo, C.; Plhalova, L.; Svobodova, Z.; Faggio, C. Embryotoxicity of atrazine and its degradation products to early life stages of zebrafish (Danio rerio). Environ. Toxicol. Pharmacol. 2020, 77, 103370. [CrossRef]

2. Fiorino, E.; Sehonova, P.; Plhalova, L.; Blahova, J.; Svobodova, Z.; Faggio, C. Effects of glyphosate on early life stages: Comparison between Cyprinus carpio and Danio rerio. Environ. Sci Pollut. Res. 2018, 25, 8542-8549. [CrossRef] [PubMed]

3. Cahova, J.; Blahova, J.; Plhalova, L.; Svobodova, Z.; Faggio, C. Do single-component and mixtures selected organic UV filters induce embryotoxic effects in zebrafish (Danio rerio). Water 2021, 13, 2203. [CrossRef]

4. Kalichak, F.; Idalencio, R.; Rosa, J.G.S.; de Oliveira, T.A.; Koakoski, G.; Gusso, D.; de Abreu, M.S.; Giacomini, A.C.V.; Barcellos, H.H.A.; Fagundes, M.; et al. Waterborne psychoactive drugs impair the initial development of zebrafish. Environ. Toxicol. Pharmacol. 2016, 41, 89-94. [CrossRef] [PubMed]

5. Hollerova, A.; Hodkovicova, N.; Blahova, J.; Faldyna, M.; Marsalek, P.; Svobodova, Z. Microplastics as a potencial risk for aquatic environment organisms-A review. Acta Vet. Brno 2021, 90, 99-107. [CrossRef]

6. Čaloudová, H.; Čaloudová, J.; Svobodová, Z. A review of the effects of metallic nanoparticles on fish. Acta Vet. Brno 2021, 90, 331-347. [CrossRef]

7. Sehonova, P.; Tokanova, N.; Hodkovicova, N.; Kocour Kroupova, H.; Tumova, J.; Blahova, J.; Marsalek, P.; Plhalova, L.; Doubkova, V.; Dobsikova, R.; et al. Oxidative stress induced by fluoroquinolone enrofloxacin in zebrafish (Danio rerio) can be ameliorated after a prolonged exposure. Environ. Toxicol. Pharmacol. 2019, 67, 87-93. [CrossRef] [PubMed]

8. Plhalova, L.; Blahova, J.; Divisova, L.; Enevova, V.; Causcelli Di Tocco, F.; Faggio, C.; Tichy, F.; Vecerek, V.; Svobodova, Z. The effects of subchronic exposure to NeemAzal T/S on zebrafish (Danio rerio). Chem. Ecol. 2018, 34, 199-210. [CrossRef]

9. Bartoskova, M.; Dobsikova, R.; Stancova, V.; Zivna, D.; Blahova, J.; Marsalek, P.; Zelnickova, L.; Bartos, M.; Cassucelli di Tocco, F.; Faggio, C. Evaluation of ibuprofen toxicity for zebrafish (Danio rerio) targeting on selected biomarkers of oxidative stress. Neuroendocrinol. Lett. 2013, 34, 102-108.

10. Parriono, V.; Cappello, T.; Costa, G.; Cannava, C.; Sanfilippo, M.; Fazio, F. Comparative study of haematology of two teleost fish (Mugil cehpalus and Carassius auratus) from different environments and feeding habits. Eur. Zool. J. 2021, 88, 540-548.

11. Rzymski, P.; Drewek, A.; Klimaszyk, P. Pharmaceutical pollution of aquatic environment: An emerging and enormous challange. Limnol. Rev. 2017, 17, 97-107. [CrossRef]

12. Doyle, S.; Meade, E.; Fowley, C.; Garvey, M. A comprehensive review of current environmental pollutants of pharmaceutical, agricultural and industrial origin. Eur. J. Exp. Biol. 2020, 10, 5.

13. Skocovska, M.; Ferencik, M.; Svoboda, M.; Svobodova, Z. Residues of selected sulfonamides, non-sterioidal anti-inflammatory drugs and analgesics-antipyretics in surface water of the Elbe river basin (Czech Republic). Vet. Med. 2021, 66, 208-218. [CrossRef]

14. Sehonova, P.; Svobodova, Z.; Dolezelova, P.; Vosmerova, P.; Faggio, C. Effects of waterborne antidepressants on non-target animals living in the aquatic environment: A review. Sci. Total Environ. 2018, 631, 789-794. [CrossRef]

15. Lopes, D.G.; Duarte, I.A.; Antunes, M.; Fonseca, V.F. Effects of antidepressants in the reproduction of aquatic organisms: A meta-analysis. Aquat. Toxicol. 2020, 227, 105569. [CrossRef]

16. Yang, H.; Liang, X.; Zhao, Y.; Gu, X.; Mao, Z.; Zeng, Q.; Chen, H.; Martyniuk, C.J. Molecular and behavioral responses of zebrafish embryos/larvae after sertraline exposure. Ecotoxicol. Environ. Saf. 2021, 208, 111700. [CrossRef] [PubMed]

17. Tarleton, E.K.; Kennedy, A.G.; Daley, C. Primer for nutritionists: Managing the side effects of antidepressants. Clin. Nutr. ESPEN 2016, 15, 126-133. [CrossRef]

18. OECD.stat. 2020. Available online: https:/ / stats.oecd.org (accessed on 29 September 2021).

19. Silva, L.J.G.; Lino, C.M.; Meisel, L.M.; Pena, A. Selective serotonin re-uptake inhibitors (SSRIs) in the aquatic environment: An ecopharmacovigilance approach. Sci. Total Environ. 2012, 437, 185-195. [CrossRef] [PubMed]

20. Stahl, S.M. Prescriber's Guide: Antidepressants—Stahl's Essential Psychopharmacology; Cambrige University Press: London, UK, 2017; 694p.

21. Ford, A.T.; Fong, P.P. The effects of antidepressants appear to be rapid and at environmentally relevant concentrations. Environ. Toxicol. Chem. 2016, 35, 794-798. [CrossRef] [PubMed]

22. Richmond, E.K.; Rosi-Marshall, E.J.; Lee, S.S.; Thompson, R.M.; Grace, M.R. Antidepressants in stream ecosystems: Influence of selective serotonin reuptake inhibitors (SSRIs) on algal production and insect emergence. Freshw. Sci. 2016, 35, 3. [CrossRef]

23. Sehonova, P.; Plhalova, L.; Blahova, J.; Doubkova, V.; Marsalek, P.; Prokes, M.; Tichy, F.; Skladana, M.; Fiorino, E.; Mikula, P.; et al. Effect of selected tricyclic antidepressants on early-life stages of common carp (Cyprinus carpio). Chemosphere 2017, 185, 1072-1080. [CrossRef] 
24. Sehonova, P.; Hodkovicova, N.; Urbanova, M.; Örn, S.; Blahova, J.; Svobodova, Z.; Faldyna, M.; Chloupek, P.; Briedikova, K.; Carlsson, G. Effects of antidepressants with different modes of action on early life stages of fish and amphibians. Environ. Pollut. 2019, 254, 112999. [CrossRef]

25. Sehonova, P.; Zikova, A.; Blahova, J.; Svobodova, Z.; Chloupek, P.; Kloas, W. mRNA expression of antioxidant and biotransformation enzymes in zebrafish (Danio rerio) embryos after exposure to the tricyclic antidepressant amitriptyline. Chemosphere 2019, 217, 516-521. [CrossRef]

26. Kellner, M.; Porseryd, T.; Porsch-Hällström, I.; Hansen, S.H.; Olsén, K.H. Environmentally relevant concentrations of citalopram partially inhibit feeding in the three-spine stickleback (Gasterosteus aculeatus). Aquat. Toxicol. 2015, 158, 165-170. [CrossRef]

27. Foran, C.M.; Weston, J.; Slattery, M.; Brooks, B.W.; Huggett, D.B. Reproductive assessment of Japanese medaka (Oryzias latipes) following a four-week fluoxetine (SSRI) exposure. Arch. Environ. Contam. Toxicol. 2003, 46, 511-517. [CrossRef]

28. Schultz, M.M.; Furlong, E.T.; Kolpin, D.W.; Werner, S.; Schoenfuss, H.L.; Barber, L.B.; Blazer, V.S.; Norris, D.O.; Vajda, A.M. Antidepressants pharmaceuticals in two U.S. effluent-impacted streams: Occurrence and fate in water and sediment and selective uptake in fish neural tissue. Environ. Sci. Technol. 2010, 44, 1918-1925. [CrossRef]

29. Wu, M.; Xiang, J.; Chen, F.; Fu, C.; Xu, G. Occurrence and risk assessment of antidepressants in Huangpu River of Shanghai, China. Environ. Sci. Pollut. Res. 2017, 24, 220291-220299. [CrossRef] [PubMed]

30. Magni, S.; Parolini, M.; Della Torre, C.; de Oliveira, L.F.; Catani, M.; Guzzinati, R.; Cavazzini, A.; Binelli, A. Multi-biomarker investigation to assess toxicity induced by two antidepressants on Dreissena polymorpha. Sci. Total Environ. 2017, 578, 452-459. [CrossRef]

31. Yang, M.; Liu, S.; Hu, L.; Zhan, J.; Lei, P.H.; Wu, M.H. Effects of the antidepressant, mianserin, on early development of fish embryos at low environmentally relevant concentrations. Ecotoxicol. Environ. Saf. 2018, 150, 144-151. [CrossRef] [PubMed]

32. Vaclavik, J.; Sehonova, P.; Hodkovicova, N.; Vecerkova, L.; Blahova, J.; Franc, A.; Marsalek, P.; Mares, J.; Tichy, F.; Svobodova, Z.; et al. The effect of foodborne sertraline on rainbow trout (Oncorhychus mykiss). Sci. Total Environ. 2020, 708, 135082. [CrossRef] [PubMed]

33. De Farias, O.N.; Oliveira, R.; Sousa-Moura, D.; Silva de Oliveira, R.C.; Rodrigues, M.A.C.; Andrade, T.S.; Domingues, I.; Camargo, N.S.; Muchlmann, L.A.; Grisolia, C.K. Exposure to low concentration of fluoxetine affects development, behaviour and acetylcholinesterase activity of zebrafish embryos. Comp. Biochem. Physiol. C 2019, 215, 1-8. [CrossRef]

34. Nowakowska, K.; Giebultowicz, J.; Kamaszewski, M.; Adamski, A.; Szudrowicz, H.; Ostaszewska, T.; Solarska-Dziecolowska, U.; Nalecz-Jawecki, G.; Wroczynski, P.; Drobniewska, A. Acute exposure of zebrafish (Danio rerio) larvae to environmental concentrations of selected antidepressants: Bioaccumulation, physiological and histological changes. Comp. Biochem. Physiol. Part-C Toxicol. Pharmacol. 2020, 229, 108670. [CrossRef] [PubMed]

35. Aderemi, A.O.; Hunter, C.; Pahl, O.; Roberts, J.; Shu, X. Developmental anomalies and oxidative stress responses in zebrafish (Danio rerio) following embryonic exposure to human pharmaceuticals. J. Toxicol. Environ. Health 2020, 5, $109-125$.

36. Pelli, M.; Connaughton, V.P. Chronic exposure to environmentally-relevant concentration of fluoxetine (Prozac) decreases survival, increases abnormal behaviors, and delay predator escape responses in guppies. Chemosphere 2015, 139, 202-209. [CrossRef]

37. Woodman, S.G.; Steinkey, D.; Dew, W.A.; Burket, S.R.; Brooks, B.W.; Pyle, G.G. Effects of sertraline on behavioral indices of crayfish Orconectes virilis. Ecotoxicol. Environ. Saf. 2016, 134, 31-37. [CrossRef] [PubMed]

38. Liu, K.; Garcia, A.; Park, J.J.; Toliver, A.A.; Ramos, L.; Alzenman, C. Early developmental exposure to fluoxetine and citalopram results in different neurodevelopmental outcomes. Neuroscience 2021, 467, 110-121. [CrossRef] [PubMed]

39. Acar, Ü.; Parrino, V.; Kesbic, O.S.; Lo Paro, G.; Saoca, C.; Abbate, F.; Yilmaz, S.; Fazio, F. Effects of different levels of pomegranate seed oil on some blood parameters and disease resistance against Yersinia ruckeri in rainbow trout. Front. Physiol. $2018,9,596$. [CrossRef]

40. Kesbic, O.S.; Parrino, V.; Acar, Ü.; Yilmaz, S.; Lo Paro, G.; Fazio, F. Effects of monterey cypress (Cupressus macrocarpa hartw) leaf essential oil as a dietary supplement on growth performance and haematological and biochemical parameters of common carp (Cyprinus carpio L.). Ann. Anim. Sci. 2020, 20, 1411-1426. [CrossRef]

41. Sula, E.; Aliko, V.; Barcelo, D.; Faggio, C. Combined effects of moderate hypoxia, pesticide and PCBs upon Crucian Carp fish, Carassius carrasius, from a freshwater lake-in situ ecophysiological approach. Aquat. Toxicol. 2020, 228, 105644. [CrossRef]

42. Forouhar Vajargah, M.; Mohsenpour, R.; Yalsuyi, A.M.; Galangash, M.M.; Faggio, C. Evaluation of histopathological effect of Roach (Rutilus rutilus caspicus) in exposure to sub-lethal concentrations of Abamectin. Water Air Soil Pollut. 2021, $232,188$. [CrossRef]

43. Hamed, H.; Ismal, S.; Faggio, C. Effect of allicin on antioxidant defense system, after carbofuran exposure in Nile tilapia, Oreochromis niloticus. Comp. Biochem. Physiol. C Toxicol. 2021, 240, 108919. [CrossRef]

44. Stara, A.; Pagano, M.; Capillo, G.; Fabrello, J.; Sandova, M.; Vazzana, I.; Zuskova, E.; Velisek, J.; Matozzo, V.; Faggio, C. Assessing the effects of neonicotinoid insecticide on the bivalve mollusc Mytilus galloprovincialis. Sci. Total Environ. 2020, 700, 134914. [CrossRef] [PubMed]

45. Stara, A.; Pagano, M.; Capillo, G.; Fabrello, J.; Sandova, M.; Albano, M.; Zuskova, E.; Velisek, J.; Matozzo, V.; Faggio, C. Acute effects of neonicotinoid insecticides on Mytilus galloprovincialis: A case study with the active compound thiacloprid and the commercial formulation Calypso 480 S. Ecotoxicol. Envrion. Saf. 2020, 203, 110980. [CrossRef]

46. Pagano, M.; Stara, A.; Aliko, V.; Faggio, C. Impact of neonicotinoids to aquatic invertebrates—in vitro studies on Mytilus galloprovincialis: A review. J. Mar. Sci. Eng. 2020, 8, 801. [CrossRef] 
47. Stara, A.; Pagano, M.; Albano, M.; Savoca, S.; Di Bella, G.; Albergamo, A.; Zuskova, E.; Sandova, M.; Velisek, J.; Fabrello, J.; et al. Effects of long-term exposure of Mytilus galloprovincialis to thiacloprid: A multibiomarker approach. Environ. Pollut. 2021, 289, 117892. [CrossRef]

48. Petrovic, T.G.; Gavrilovic, B.R.; Radovanovic, T.B.; Despotovic, S.G.; Gavric, J.P.; Kijanovic, A.; Mirc, M.; Kolarov Tomasevic, N.; Faggio, C.; Prokic, M. Impact of desiccation pre-exposure on deltamethrin-induced oxidative stress in Bombina variegata juveniles. Comp. Biochem. Physiol. C Toxicol. 2021, 250, 109191.

49. Sharma, R.; Jindal, R.; Faggio, C. Impact of cypermethrin in nephrocytes of freshwater fish Catla catla. Enviorn. Toxicol. Pharmacol. 2021, 88, 103739. [CrossRef] [PubMed]

50. Forouhar Vajargah, M.; Namin, J.I.; Mohsenpour, R.; Yalsuyi, A.M.; Prokic, M.D.; Faggio, C. Histological effects of sublethal concentrations of insecticide Lindane on intestinal tissue of grass carp (Ctenopharyngodon idella). Vet. Res. Commun. 2021. [CrossRef]

51. Sharma, S.; Iqbal Dar, O.; Singh, K.; Kaur, A.; Faggio, C. Triclosan elicited biochemical and transcriptomic alterations in Labeo rohita larvae. Environ. Toxicol. Pharmacol. 2021, 88, 103748. [CrossRef]

52. Part, P.; Castano, A.; Bengtsson, B.E. Testing in Aquatic Ecotoxicology: What are the scientific conditions for the '3R' concept? In Regulating Chemical Risks; Eriksson, J., Gilek, M., Rudén, C., Eds.; Springer: Dordrecht, The Netherlands, 2010 ; pp. 99-119.

53. Schiffelers, M.J.W.A.; Blaauboer, B.J.; Bakker, W.E.; Beken, S.; Hendriksen, C.F.M.; Koeter, H.B.W.M.; Krul, C. Regulatory acceptance and use of 3R models for pharmaceuticals and chemicals: Expert opinions on the state of affairs and the way forward. Regul. Toxicol. Pharmacol. 2014, 69, 41-48. [CrossRef]

54. Capela, R.; Garric, J.; Castro, L.F.C.; Santos, M.M. Embryo bioassays with aquatic animals for toxicity testing and hazard assessment of emerging pollutants: A review. Sci. Total Environ. 2020, 705, 135740. [CrossRef]

55. ISO 7346. Water Quality-Determination of Acute Lethal Toxicity of Substances to a Freshwater Fish [Brachydanio Rerio Hailton-Buchanen (Teleostei, Cyprinidae)]_Part I: Static Method; American National Standards Institute: New York, NY, USA, 1996.

56. Christensen, M.; Markussen, B.; Baun, A.; Halling-Sørensen, B. Probabilistic environmental risk characterization of pharmaceuticals in sewage treatment plant discharges. Chemosphere 2009, 77, 351-358. [CrossRef] [PubMed]

57. Lajuenesse, A.; Gagnon, C.; Sauve, S. Determination of basic antidepressants and their N-desmethyl metabolites in raw sewage and wastewater using solid-phase extraction and liquid chromatography-tandem mass spektrometry. Anal. Chem. 2008, 802, 5325-5333. [CrossRef]

58. OECD. OECD Guidelines for the Testing of Chemicals, Test No. 236: Fish Embryo Acute Toxicity (FET) Test; OECD Publishing: Paris, France, 2013; 22p.

59. Nagel, R. DarT: The embryo test with the zebrafish Danio rerio-a general model in ecotoxicology and toxicology. ALTEX 2002, 19, 38-48. [PubMed]

60. ASTM E1439-12. Standard Guide for Conducting the Frog Embryo Teratogenesis Assay-Xenopus (FETAX); ASTM International: West Conshohocken, PA, USA, 2019.

61. Jijie, R.; Mihalache, G.; Balmus, I.M.; Strungaru, S.A.; Baltag, E.S.; Ciobica, A.; Nicoara, M.; Faggio, C. Zebrafish as a screening model to study the single and joint effects of antibiotics. Pharmaceuticals 2021, 14, 578. [CrossRef] [PubMed]

62. Plhalova, L.; Sehonova, P.; Blahova, J.; Doubkova, V.; Tichy, F.; Faggio, C.; Berankova, P.; Svobodova, Z. Evaluation of tramadol hydrochloride toxicity to juvenile zebrafish-morphological, antioxidant and histological responses. Appl. Sci. 2020, 10, 2349. [CrossRef]

63. Freitas, R.; Silvestro, S.; Pagano, M.; Coppola, F.; Meucci, V.; Battaglia, F.; Intorre, L.; Soares, A.M.V.M.; Pretti, C.; Faggio, C. Impacts of salicylic acid in Mytilus galloprovincialis exposed to warming conditions. Environ. Toxicol. Pharmacol. 2020, 80, 103448. [CrossRef]

64. Freitas, R.; Silvestro, S.; Coppola, F.; Meucci, V.; Battaglia, F.; Intorre, L.; Soares, A.M.V.M.; Pretti, C.; Faggio, C. Biochemical and physiological responses induced in Mytilus galloprovincialis after a chronic exposure to Salicylic Acid. Aquat. Toxicol. 2019, 214, 105258. [CrossRef]

65. Turani, B.; Aliko, V.; Faggio, C. Amphibian embryos as an alternative model to study the pharmaceutical toxicity of cyclophosphamide and ibuprofen. J. Biol. Res. 2019, 92, 72-76. [CrossRef]

66. Aliko, V.; Mehmeti, E.; Qirjo, M.; Faggio, C. Drink and sleep like a fish- goldfish as a behavior model to study pharmaceutical effects in freshwater ecosystem. J. Biol. Res. 2019, 92, 1-4. [CrossRef]

67. Martín, J.; Camacho-Muñoz, D.; Santos, J.L.; Aparicio, I.; Alonso, E. Occurrence of pharmaceutical compounds in wastewater and sludge from wastewater treatment plants: Removal and ecotoxicological impact of wastewater discharges and sludge disposal. J. Hazard. Mater. 2012, 239-240, 40-47. [CrossRef] [PubMed]

68. Martinez, R.; Vera-Chang, M.N.; Haddad, M.; Zon, J.; Navarro-Martin, L.; Trudeau, V.L.; Menningen, J.A. Developmental fluoxetine exposure in zebrafish reduces offspring basal cortisol concentration via life stage-dependent maternal transmission. PLoS ONE 2019, 14, e0212577. [CrossRef] [PubMed]

69. Branchet, P.; Arpin-Pont, L.; Piram, A.; Biossery, P.; Wong-Wah-Chung, P.; Doumenq, P. Pharmaceuticals in the marine environment: What are the present challenges in their monitoring? Sci. Total Environ. 2021, 766, 142644. [CrossRef]

70. Minguez, L.; Poi, C.D.; Farcy, E.; Ballandonne, C.; Benchouala, A.; Bojic, C.; Cossu-Leguille, C.; Costil, K.; Serpentini, A.; Lebel, J.M.; et al. Comparison of the sensitivity of seven marine and freshwater bioassys as regards antidepressant toxicity assessment. Ecotoxicology 2014, 23, 1744-1754. [CrossRef] 
71. Ziegler, M.; Eckstein, H.; Köhler, H.R.; Tisler, S.; Zwiener, C.; Triebskorn, R. Effects of the antidepressants citalopram and venlafaxine on the big ramshorn snail (Planorbarius corneus). Water 2021, 13, 1722. [CrossRef]

72. Lammer, E.; Carr, G.J.; Wendler, K.; Rawlings, J.M.; Belanger, S.E.; Braunbeck, T. Is the fish embryo toxicity test (FET) with the zebrafish (Danio rerio) a potential alternative for the fish acute toxicity test? Comp. Biochem. Physiol. C Toxicol. Pharmacol. 2009, 149, 196-209. [CrossRef]

73. Poi, C.D.; Evariste, L.; Serpentini, A.; Halm-Lemeille, M.P.; Lebel, J.M.; Costil, K. Toxicity of five antidepressant drugs on embry-larval development and metamorphosis success in the Pacific oyster, Crassostrea gigas. Environ. Sci. Pollut. Res. 2014, 21, 13302-13314. [CrossRef]

74. Zivna, D.; Plhalova, L.; Chromcova, L.; Blahova, J.; Prokes, M.; Skoric, M.; Marsalek, P.; Praskova, E.; Stepanova, S.; Svobodova, Z. The effects of ciprofloxacin on early life stage of common carp (Cyprinus carpio). Environ. Toxicol. Chem. 2016, 35, 1733-1740. [CrossRef]

75. Brooks, B.W.; Foran, C.M.; Richards, S.M.; Weston, J.; Turner, P.K.; Stanley, J.K.; Solomon, K.R.; Slattery, M.; La Point, T.W. Aquatic ecotoxicology of fluoxetine. Toxicol. Lett. 2003, 142, 169-183. [CrossRef]

76. Oliveira, A.C.; Fascineli, M.L.; Andrade, T.S.; Sousa-Moura, D.; Domingues, I.; Camargo, N.S.; Oliveira, R.; Brisolia, C.K.; Villacis, R.A.R. Exposure to tricyclic antidepressant nortriptyline affects early-life stages of zebrafish (Danio rerio). Ecotoxicol. Environ. Saf. 2021, 210, 111868. [CrossRef] [PubMed]

77. Warkman, A.S.; Krieg, P.A. Xenopus as a model system for vertebrate heart development. Semin. Cell. Dev. Biol. 2007, 18, 46-53. [CrossRef] [PubMed]

78. De Luca, E.; Zaccaria, G.M.; Hadboud, M.; Rizzo, G.; Ponzini, R.; Marbiducci, U.; Santoro, M.M. ZebraBeat: A flexible platform for the analysis of the cardiac rate in zebrafish embryos. Sci. Rep. 2014, 4, 4989. [CrossRef]

79. Zakaria, Z.; Benslimane, F.M.; Nasrallah, G.K.; Shurbaji, S.; Younes, N.N.; Mraiche, F.; Da' as, S.I.; Yalcin, H.C. Using zebrafish for investigating the molecular mechaisms of drug-induced cardiotoxicity. BioMed Res. Int. 2018, 2018, 1642684. [CrossRef] [PubMed]

80. Bachour, R.L.; Golovko, O.; Kellner, M.; Pohl, J. Behavioral effects of citalopram, tramadol, and binary mixture in zebrafish (Danio rerio) larvae. Chemosphere 2020, 238, 124587. [CrossRef] [PubMed] 